\title{
PRECISIONS CONCERNING THE DISTRIBUTION AND IDENTIFICATION OF MIOCENE HOMINOIDS FROM INDIA
}

\author{
Martin PICKFORD ${ }^{I}$ and Brahma N. TIWARI ${ }^{2}$ \\ ${ }^{1}$ College de France and Département Histoire de la Terre, CR2P, UMR 7207 \\ du CNRS, 8, rue Buffon, 75005, Paris, France (pickford@mnhn.fr) \\ ${ }^{2}$ Wadia Institute of Himalayan Geology, Dehra Dun 248 001, India \\ (bntiwari@wihg.res.in)
}

Pickford, M. \& Tiwari, B. N. 2010. Precisions concerning the distribution and identification of Miocene hominoids from India. [Precisiones respecto a la distribución e identificación de los hominoideos miocenos de la India.] Revista Española de Paleontología, 25 (2), 107-121. ISSN 0213-6937.

\begin{abstract}
During the past four decades, the Indian Subcontinent has been a focus of palaeoanthropological research on account of the abundance of Middle and Late Miocene hominoid fossils that have been reported from it. In India, well known hominoid-bearing localities occur at Ramnagar (Lower Siwaliks) and Hari Talyangar (Middle Siwaliks), but there are less well known occurrences in the literature, such as the material from Dhara and Nungarh near Kalagarh in Pauri Garhwal District, not far from the Nepalese and Chinese frontiers. Reports of the discovery of hominoid fossils at other poorly known localities at Ramchand Ridge and Dhiran near Ramnagar (Jammu \& Kashmir) and Bandal (Himachal Pradesh) formed the basis for claims that hominoids existed in the subcontinent earlier than the Chinji zone. If so, then current views of hominoid palaeobiogeography would need to be modified to the extent that an earlier passage of large hominoids out of Africa towards the Indian subcontinent than is generally accepted, would need to be postulated. We also examine a claim for the persistence of large hominoids up to the Mio-Pliocene boundary (ca 5.5 Ma) on the basis of a tooth found near Bharari, east of Hari Talyangar.

The aim of this paper is to examine the soundness of the basis of claims for the presence of pre-Chinji large bodied hominoids in the region and for their persistence in the subcontinent up to the end of the Miocene epoch.

With this aim in mind, in January, 2009, the authors surveyed the zone northwest of Dera Gopipur; 1) to locate the place from which a partial set of upper and lower teeth attributed to Ramapithecus cf. punjabicus were collected by S.S. Gupta and B.C. Verma in the 1978-79 field season of the Geological Survey of India, 2) to recover biochronologically informative faunal remains. No such faunal remains were found, making it difficult to substantiate the claims of Lower Siwalik age for the deposits. Other published reports of the presence of early hominoids in India were also examined, but the sites were not visited.
\end{abstract}

Key Words: Hominoidea, Siwaliks, Miocene, India, Geological context, Distribution.

\section{RESUMEN}

Durante las últimas cuatro décadas el subcontinente Indio ha sido un foco de interés para la investigación paleoantropológica, dada la abundancia de hallazgos de hominoideos fósiles del Mioceno Medio y Final. En la India son bien conocidas las localidades con restos de hominoideos de Ramnagar (Siwaliks inferior) y Hari Talyangar (Siwaliks medio), pero hay otros hallazgos menos conocidos en la bibliografía, como es el caso del material procedente de Dhara y Nungarh cerca de Kalagarh en el distrito de Pauri Garhwal, no muy lejos de la frontera con Nepal y China. Informes sobre el descubrimiento de hominoideos fósiles en otras localidades poco conocidas como Ramchand Ridge y Dhiran cerca de Ramnagar (Jammu y Cachemira) y Bandal (Himachal Pradesh) forman la base para fundamentar que los hominoideos existían en el subcontinente antes de la zona de Chinji. Si esto es así, las ideas actuales sobre la paleobiogeografía de los hominoideos deberían ser modificadas, con la inclusión de una salida más temprana de los grandes hominoideos desde África hacia el subcontinente Indio previa a la generalmente aceptada. Otra afirmación que se analiza es la persistencia de los grandes hominoideos hasta el límite Mio-Plioceno (ca. 5,5 M.a.) de acuerdo con el hallazgo de un diente cerca de Bharari, al este de Hari Talyangar.

El propósito de este trabajo es examinar la solidez de los argumentos en los que se basa la afirmación de la presencia de grandes hominoideos pre-Chinji en la región y su supervivencia hasta final de la época Miocena en el subcontinente. 
Con esta idea los autores en enero de 2009 investigaron la región noroeste de Dera Gopipur con el propósito de; 1) localizar el lugar en el que se había encontrado un conjunto parcial de dientes superiores e inferiores atribuidos a Ramapithecus cf. punjabicus, recolectados por S.S. Gupta y B.C. Verma en la campaña de campo del Geological Survey of India de 1978-79; 2) obtener restos de fauna que pudieran aportar una información biocronológica más precisa. Estos restos no fueron encontrados, por lo que la confirmación de la edad de los depósitos de Siwalik inferior sigue siendo problemática. También se han examinado otros trabajos publicados sobre la presencia de hominoideos tempranos en la India, aunque no se han visitado las localidades.

\section{Palabras clave: Hominoidea, Siwaliks, Mioceno, India, contexto geológico, distribución.}

\section{INTRODUCTION}

During the past four decades, several papers have been published recording the discovery of fossil hominoids in Lower Siwalik strata of India, some of which were reported to be older than the Chinji Zone (equivalent to MN 7/8 in Europe, ca 13-11.5 Ma), some as old as 18.3 Ma (Gupta et al., 1979, 1982) which would make them equivalent to MN 3 or MN 4 in the European mammal zonation. If these reports are correct, then biogeographic scenarios concerning the emigration of large hominoids out of Africa towards the Indian Subcontinent (via Europe?) would need to be re-assessed (Andrews et al., 1999). One of the aims of this contribution, therefore, is to examine reports of Lower Siwalik fossil hominoid specimens from various localities in Northern India. The fossils concerned are from Dera Gopipur and Bandal (Himachal Pradesh), Ramchand Ridge and Dhiran (Jammu \& Kashmir) and Dhara and Nungarh (Uttar Pradesh). These fossils have generally been interpreted by their respective authors as providing evidence for the presence of hominoids in India earlier than their earliest records in Pakistan. The second aim is to assess whether a report of the persistence of hominoids in India up to the Mio-Pliocene boundary (5.5 $\mathrm{Ma}$ ), based on a tooth from Bharari (Himachal Pradesh) can be substantiated.

Pickford (1977) showed that a misidentification of a suid lower molar as a hominoid (Adaetontherium incognitum Lewis, 1934) had occurred in the Pakistan fossil record, a theme that was followed by Kelley (2005) who demonstrated how mis-attribution of suid canines to Sivapithecus Pilgrim, 1910 led to misconceptions regarding the morphology and sexual dimorphism of the taxon, and how down line interpretations (taxonomy, phylogeny) that flowed from these misconceptions were adversely affected. These kinds of mis-attribution also impact on biochronology and biogeography, two aspects that particularly concern us in this paper (Patnaik et al., 2005).

Precisions are provided regarding the discovery loci of the fossils, and the fossil material is re-identified where necessary. Several of the specimens belong to suids, whereas others are genuinely hominoid although some of the serial positions of the teeth have been misidentified.
We examine each case separately on a locality by locality basis. In the case of the supposedly Mio-Pliocene (5.5 Ma) Bharari hominoid, we re-interpret the age of the fossil relative to the palaeomagnetic stratigraphy of the deposits using an updated GPTS and conclude that the specimen is likely to be older than $7.5 \mathrm{Ma}$.

Details concerning the location of the discovery of a set of hominoid teeth near Dera Gopipur (Gupta et al., 1982) are provided, and precisions are given concerning a hominoid upper molar from Dhara, Kalagarh District (Sahni et al., 1974, 1980, 1983) and a lower premolar from Nungarh (Tiwari, 1982) in order to complete the known geographic distribution of hominoid fossils in the country. Two supposed hominoid specimens from Ramchand Ridge and Dhiran near Ramnagar (Jammu \& Kashmir; Gupta et al., 1979, 1982) are re-assessed as are two specimens from Bandal (Himachal Pradesh; Gupta, 1969).

\section{DERA GOPIPUR}

\section{PREVIOUS RESULTS}

Gupta et al. $(1979,1982)$ reported the discovery of associated hominoid teeth from an area northwest of Dera Gopipur, Kangra District, Himachal Pradesh, India, that were collected during the 1978-79 field season of the Geological Survey of India (Verma et al., 2002). The seven isolated teeth were attributed to Ramapithecus cf. punjabicus (Pilgrim, 1910).

In the 1979 report, the locality was given as "around Mangarh". In the 1982 paper, the authors provided a geological map (their figure 1) on which the discovery locus (GVT) and the line of the stratigraphic section (s-s) are marked, a stratigraphic section (their figure 2) on which the Ramapithecus level and a Fort is marked, a photograph (their plate 1) on which the hominoid site (GVT) was marked, and written descriptions in the text, in which reference is made to a sediment exposure 50 metres north of the main road (Dera Gopipur - Kangra) close to a footpath leading to the village of Gharat. In the publication by Verma et al. (2002), the locality is given as $1.5 \mathrm{~km}$ south of Bankhandi, northwest of Dera Gopipur (Fig. 1), Kangra (H.P.) and the horizon as Chinji. 


\section{CONTEXT}

In January, 2009, the authors surveyed the region between Mangarh Fort and Bankhandi on the northeast side of the tarred road, and paid particular attention to the indications provided in the paper by Gupta et al. (1982) concerning the discovery locus of a set of hominoid teeth. It was found that some of the indications provided did not agree with each other. The only outcrop within 50 metres of the road in the vicinity of the point GVT marked on the geological map is at $31^{\circ} 56^{\prime} 36.3^{\prime \prime} \mathrm{N}: 76^{\circ} 11^{\prime} 49.3{ }^{\prime \prime} \mathrm{E}$. The spot marked GVT on the photograph in Gupta et al. (1982: plate 1 ) is at $31^{\circ} 55^{\prime} 50.6^{\prime \prime} \mathrm{N}: 76^{\circ} 12^{\prime} 28.8^{\prime \prime} \mathrm{E}, 1.75 \mathrm{~km}$ southeast of the spot marked on the map in the same paper. A second fossiliferous locality near Pakhrun, marked (F) on the same map (31 $\left.56^{\prime} 18.1^{\prime \prime} \mathrm{N}: 76^{\circ} 12^{\prime} 16.3^{\prime \prime} \mathrm{E}\right)$, is midway between the GVT map location and the GVT photo location. The Fort which features in the stratigraphic section is at $31^{\circ} 55^{\prime} 28.7^{\prime \prime} \mathrm{N}: 76^{\circ} 12^{\prime} 35.23^{\prime \prime} \mathrm{E}, 2.4 \mathrm{~km}$ south of the line of section marked in Gupta et al. (1982: fig. 1). The positions of the section and the various points are indicated in figures 2 and 3.

The only fossil that the authors found was a fragment of crocodile bone from the exposures near point $(\mathrm{F})$ of Gupta et al. (1982) (point 3 in Fig. 2). Extended searches at the two points labelled GVT (points 1 and 2 in Fig. 2) failed to yield a single fossil, but screening was not tried.

It should be noted that Gupta et al. (1982) mentioned that the roadside exposure of sediment yielded numerous bone fragments dominated by chelonians, a few bovid post-cranial bones and a possible tragulid tooth fragment. They also reported that a "thin band of compact sandstone is profusely rich in micro-vertebrates and coprolitic material". Our examination of this sandstone band revealed that it is poorly fossiliferous, possibly azoic.

The survey carried out by the authors revealed that the map, photograph, stratigraphic section and text published in the definitive paper on these hominoid teeth are inconsistent with each other. It is concluded that the Dera

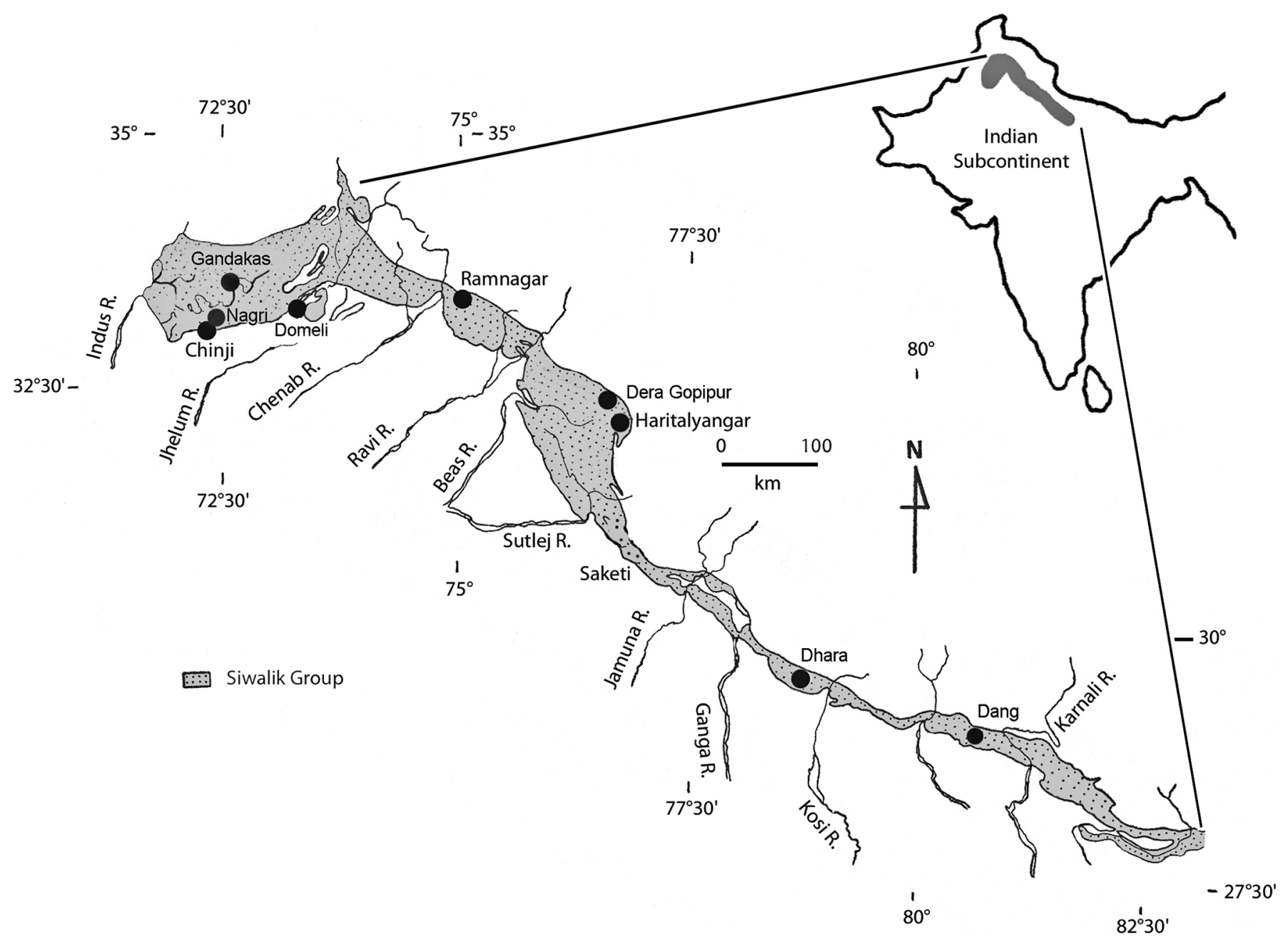

Figure 1. Distribution of Siwaliks in the Indian Subcontinent, and the location of localities from which hominoids have been reported (Bharari is $2 \mathrm{~km}$ east of Hari Talyangar; Nungarh is near Dhara). 
Gopipur hominoids have poorly constrained geographic provenience and with currently available data cannot be reliably dated either by stratigraphy or by biochronology. The hominoid fossils are re-assessed and several of the previous identifications of meristic position and side are revised. Nevertheless, the hominoid specimens from Dera Gopipur are of interest and merit further study. They are remarkable for their diminutive dimensions.

\section{PALAEOANTHROPOLOGY}

Gupta et al. $(1979,1982)$ described seven isolated, but associated teeth of a medium-sized hominoid that they attributed to Ramapithecus $\mathrm{cf}$. punjabicus. These specimens are stored at the Saketi Fossil Park, where the authors were able to study them in 2007 and 2009. Three of the teeth were illustrated by Verma et al. (2002).

Our examination of the fossils reveal that the side or meristic positions of some of the teeth were previously incorrectly identified (Table 1).

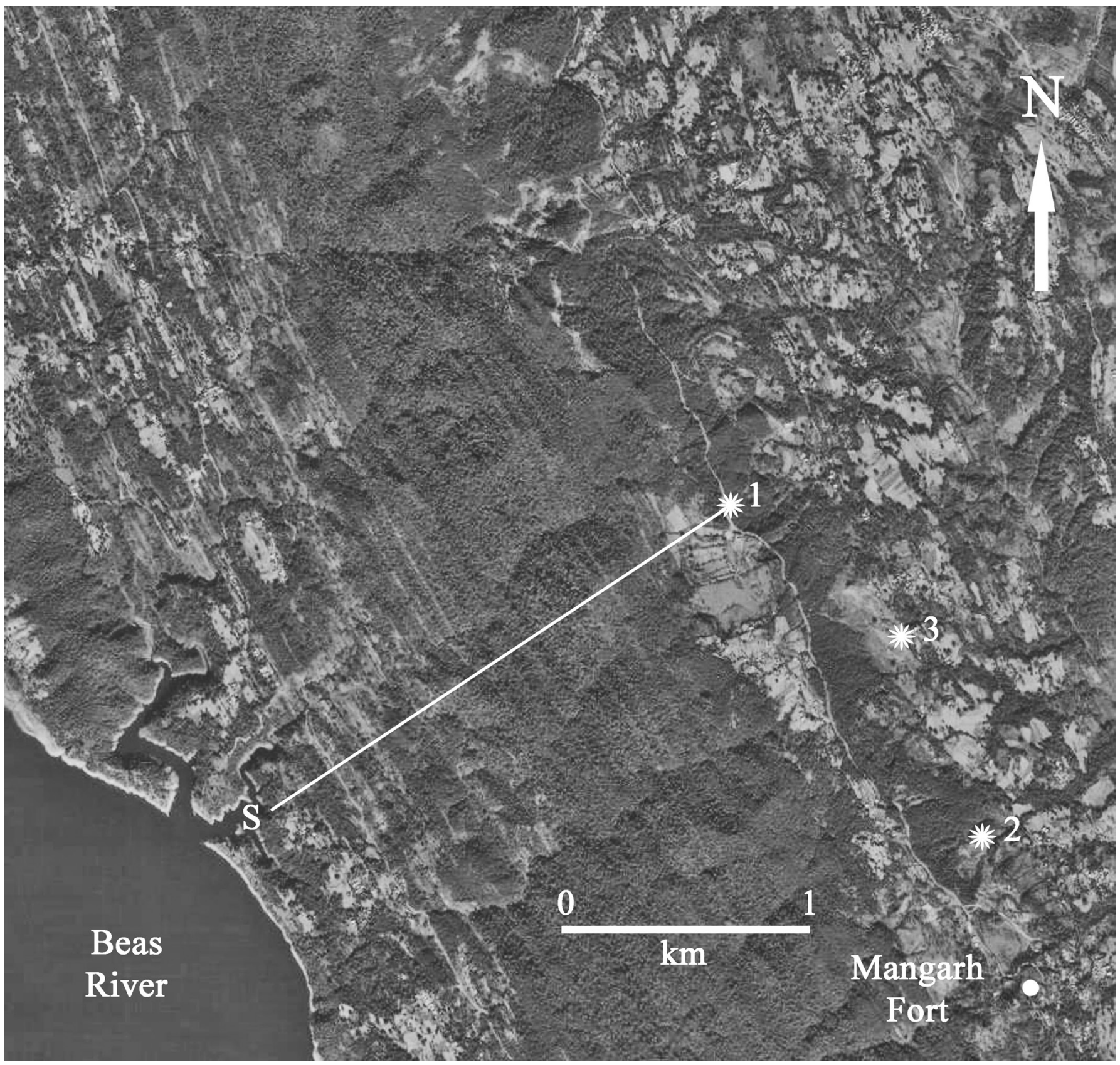

Figure 2. Location of points northwest of Dera Gopipur, Himachal Pradesh, India, discussed in the text. 1, Point GVT marked on the map in Gupta et al. (1982), corresponding to the sediment exposure 50 metres from the main road; 2, Point GVT marked on the photograph in Gupta et al. (1982); 3, Point F marked on the map in Gupta et al. (1982); S, section line marked on the map in Gupta et al. (1982) (modified from Google Earth). 
Table 1. Hominoid teeth from Dera Gopipur, Himachal Pradesh, India, stored at the Saketi Fossil Park, with measurements by the authors.

\begin{tabular}{|l|l|l|c|c|}
\hline Specimen number & Gupta et al. (1982) & This paper & Length (mm) & Breadth (mm) \\
\hline SFP 187 & Right M1/ & Left M2/ & 9.7 & - -- \\
\hline SFP 188 & Left M2/ & Right M2/ & -- & 11.7 \\
\hline SFP 189 & Right m/2 & Right m/2 & 7.8 & $9.6^{*}$ \\
\hline SFP 190 & P3/(?) & Left p/3 & -- & -8 \\
\hline SFP 191 & Left i/2 & Right m/1 fragment & -- & - \\
\hline SFP 192 & Left C1/ & Left P3/ & -- & - \\
\hline SFP 193 & Left c/1 & Indeterminate & - \\
\hline
\end{tabular}

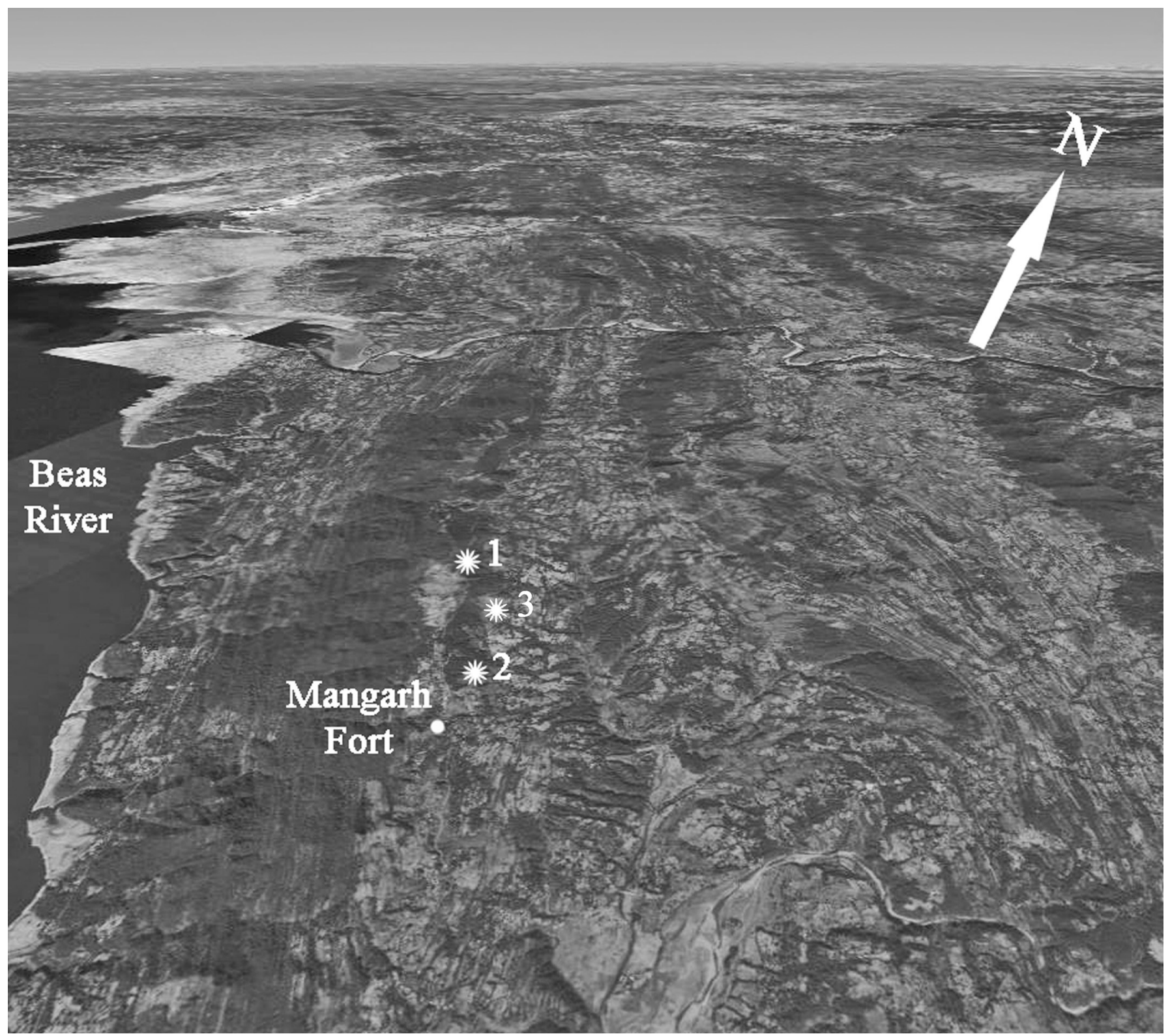

Figure 3. Oblique view of the Dera Gopipur anticline looking northwestwards, showing the position of points 1,2 and 3 (see legend of Fig. 2) to the west of the axis of the anticline. The sunken topography in light tones to the north of the numbered localities has been interpreted as representing Chinji Formation (Verma et al., 2002) although no fossils have been found to confirm this correlation (image modified from Google Earth). 
SFP 187 is a complete but moderately worn left upper molar (Fig. 4b). On the basis of its wear stage and by occlusion with the $\mathrm{m} / 2$ from the same site, we consider that this tooth is an $\mathrm{M} 2 /$. The cusps of the trigon are subequal in stature. The metacone is separated from the protocone by a shallow valley. The hypocone is smaller than the other three cusps. There is no sign of a lingual cingulum, but the mesial and distal ones are prominent.
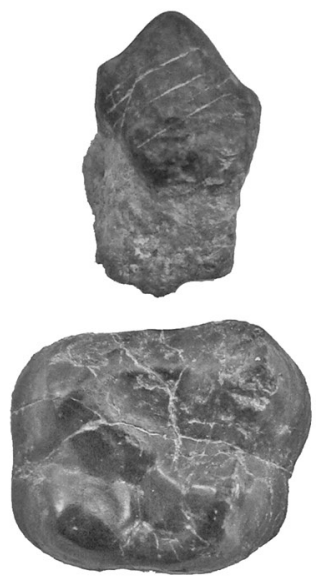

b
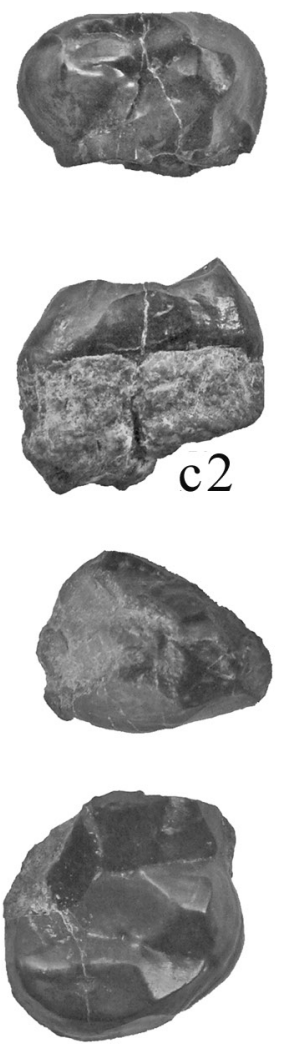

$\mathrm{a}$

d
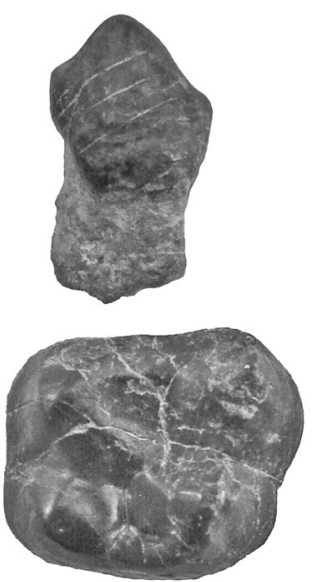

c 1
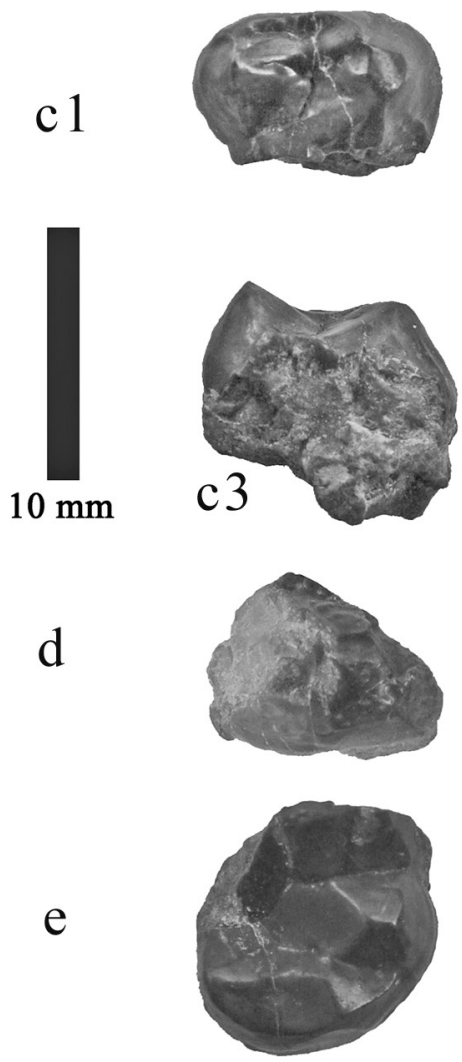

Figure 4. Hominoid teeth from Dera Gopipur, Himachal Pradesh, India. a, SFP 192, left P3/ stereo buccal view; b, SFP 187, left M2/, stereo occlusal view; c, SFP 188 , mesial half of right M2/; c1, stereo occlusal view, c2, anterior view; c3, distal view; d, SFP 190, left $\mathrm{p} / 3$ stereo occlusal view; e, SFP 189 , right $\mathrm{m} / 2$, stereo occlusal view.
Kay (1982) provided dimensions (mean and standard deviation) of the teeth of Siwalik hominoids which he attributed to three species [Sivapithecus indicus Pilgrim, 1910, Sivapithecus sivalensis (Lydekker, 1879), and Sivapithecus simonsi Kay, 1982] (Table 2). Whether the Dera Gopipur specimen is a first or a second upper molar, it is clear that it is small within the context of Siwalik hominoids, and we consider that it belongs to Sivapithecus sivalensis, or, if Sivapithecus simonsi is valid (see below), then possibly to the latter species. The specimen is close morphologically, and features similar crystodont wear facets, to a specimen from Tinau Khola, Dang Valley, Nepal (Fig. 1), hitherto attributed to Sivapithecus punjabicus (see Munthe et al., 1983).

There are two species of small Siwalik hominoids with priority over Sivapithecus simonsi Kay, 1982. The earliest named is Sivapithecus hysudricus (Pilgrim, 1927) originally classified as Hylopithecus hysudricus, with the holotype (GSI D 200, an isolated right lower molar from Hari Talyangar) (Fig. 5). The second is Bramapithecus thorpei Lewis, 1934, based on a mandible fragment (YPM 13814) containing $\mathrm{m} / 2$ and $\mathrm{m} / 3$ from near Hasnot, Pakistan. The valid name for these diminutive Siwalik hominoids is thus Sivapithecus hysudricus (Pilgrim, 1927).

SFP 188 is the anterior half of a right M2/ (Fig. 4c), possibly the antimere of SFP 187. It is missing the distal half.

SFP 189 is the rear $2 / 3$ rds of a right $\mathrm{m} / 2$ (Fig. $4 b$ ). The distal facet produced by contact against the $\mathrm{m} / 3$ is located on the bucco-distal corner of the tooth, indicating that the $\mathrm{m} / 3$ was slightly twisted buccally with respect to the long

Table 2. Dimensions (in mm) of Siwalik hominoid upper M1/s and M2/s. Dimensions are from Kay (1982) except for Tinau Khola, which is from Munthe et al. (1983), and the Dera Gopipur tooth which are the authors' measurements.

\begin{tabular}{|l|c|c|}
\hline $\begin{array}{l}\text { Species (number of } \\
\text { individuals) }\end{array}$ & $\begin{array}{c}\text { Length mean } \\
\text { (standard } \\
\text { deviation) }\end{array}$ & $\begin{array}{c}\text { Breadth mean } \\
\text { (standard } \\
\text { deviation) }\end{array}$ \\
\hline M1/ & $11.3(0.55)$ & $13.0(0.52)$ \\
\hline Sivapithecus indicus $(8)$ & 10.3 & 11.5 \\
\hline Sivapithecus sivalensis (4) & 10.4 & 10.8 \\
\hline $\begin{array}{l}\text { Sivapithecus hysudricus } \\
\text { (ex simonsi) (1) }\end{array}$ & 10.0 & 10.9 \\
\hline Tinau Khola (Nepal) (1) & 10.6 & 11.5 \\
\hline Dhara (India) (1) & 11.5 & $14.3(0.56)$ \\
\hline M2/ & 10.4 & 11.0 \\
\hline Sivapithecus indicus (7) & $13.0(0.53)$ & 11.7 \\
\hline Sivapithecus sivalensis $(4)$ & 9.7 & \\
\hline $\begin{array}{l}\text { Sivapithecus hysudricus } \\
\text { (ex simonsi) (1) }\end{array}$ & & \\
\hline Dera Gopipur (1) & & \\
\hline
\end{tabular}


axis of the tooth row. The hypoconulid is positioned in the centre line of the tooth and the small mesio-distally compressed entoconid is located lingually, with a prominent groove between it and the hypoconulid. The talonid basin is small and crowded onto the lingual half of the crown. The wear facets on this tooth are planar, shaped like crystal surfaces. Within the context of Siwalik hominoids, this tooth is small, compatible in dimensions to Sivapithecus hysudricus (see table 3).

Table 3. Dimensions (in $\mathrm{mm}$ ) of Siwalik hominoid lower second molars. Dimensions are from Kay (1982) except for the Dera Gopipur tooth which are the authors' measurements.

\begin{tabular}{|l|c|c|}
\hline $\begin{array}{l}\text { Species (number of } \\
\text { individuals) }\end{array}$ & $\begin{array}{c}\text { Length mean } \\
\text { (standard } \\
\text { deviation) }\end{array}$ & $\begin{array}{c}\text { Breadth mean } \\
\text { (standard } \\
\text { deviation) }\end{array}$ \\
\hline Sivapithecus indicus $(11)$ & $14.3(1.13)$ & $13.0(0.78)$ \\
\hline Sivapithecus sivalensis $(12)$ & $12.0(0.68)$ & $10.6(0.60)$ \\
\hline $\begin{array}{l}\text { Sivapithecus hysudricus } \\
\text { (ex simonsi) }(1)\end{array}$ & 10.0 & 9.0 \\
\hline Dera Gopipur (1) & -- & 9.6 \\
\hline
\end{tabular}

SFP 190 is a left p/3 (Fig. 4d) with a damaged crown, but preserves portions of the anterior and posterior interstitial facets made by contact with the neighbouring teeth. Because the $\mathrm{p} / 3$ is obliquely oriented in the tooth row, maximum and transverse measurements differ from mesio-distal length and bucco-lingual breadth measurements. In table 1 we provide the mesio-distal and buccolingual measurements using the interproximal facets as a guide to the orientation of the tooth in the jaw. Note that

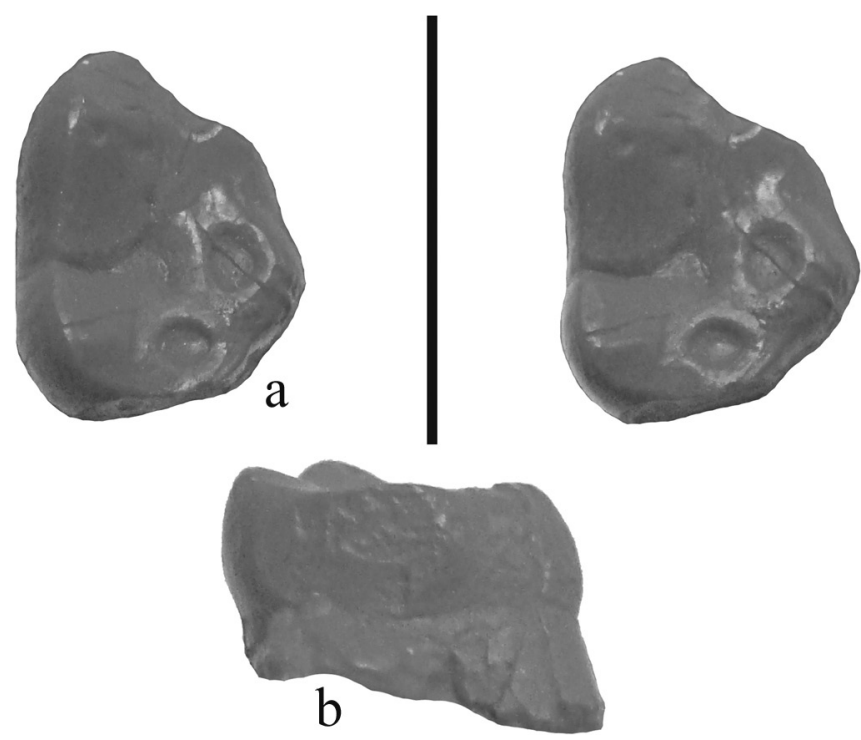

Figure 5. GSI D 200, right m/1 from Hari Talyangar, the holotype of Sivapithecus hysudricus (Pilgrim, 1927); a, stereo occlusal view of a cast; $\mathbf{b}$, lingual view (Scale: $10 \mathrm{~mm})$. the length is less than the breadth. In table 4 we provide maximum and transverse measurements, as this appears to be the way of measuring employed by Cameron et al. (1999). In the latter approach the "length" is greater than the "breadth". The tooth has an anterior cingulum, and a central fovea towards the lingual side of the tooth.

This lower premolar is exceptionally small in the context of Siwalik hominoids. It is slightly smaller than the smallest specimen known from the Potwar Plateau (GSI D-295), attributed by Kay (1982) to Sivapithecus simonsi, but here identified as Sivapithecus hysudricus.

SFP 191 is the disto-lingual corner of a right $\mathrm{m} / 1$. It preserves a large distal facet produced by contact with the

Table 4. Metric comparison (in $\mathrm{mm}$ ) of lower third premolars of Miocene hominoids from the Indian Subcontinent (data and identifications for specimens from Ramnagar, Hari Talyangar and Potwar Plateau are from Cameron et al. (1999). Values of original specimens taken from (a) Gregory \& Hellman (1926); (b) Chopra \& Kaul (1975); (c) Pilgrim (1927); (e) Pilbeam et al. (1980); (f) Preuss (1982); (g) Kay (1982); and (h) Kelley (1988). Prasad (1968) gives $9 \times 9 \mathrm{~mm}$ for GSI 18039 and Pilgrim (1927) gives 11.2 x $11.2 \mathrm{~mm}$ for GSI D-197. These measurements are evidently taken obliquely to the long axis of the teeth. We here estimate the greatest length $\mathrm{x}$ perpendicular breadth, in order for the comparisons to be realistic. (*//estimated from roots of the tooth).

\begin{tabular}{|l|c|c|l|}
\hline $\begin{array}{l}\text { Location and specimen } \\
\text { number }\end{array}$ & $\begin{array}{c}\text { Length } \\
(\mathbf{m a x})\end{array}$ & $\begin{array}{c}\text { Breadth } \\
\text { (trs) }\end{array}$ & Identification \\
\hline $\begin{array}{l}\text { Dera Gopipur, Himachal } \\
\text { Pradesh, India }\end{array}$ & & & \\
\hline SFP 190 & 8.8 & 6.5 & S. hysudricus \\
\hline Rammagar, Kashmir, India & & & \\
\hline AMNH 19411a & 11.3 & 7.2 & S. sivalensis \\
\hline $\begin{array}{l}\text { Hari Talyangar localities, } \\
\text { India }\end{array}$ & & & \\
\hline PUA 1047-69b & 11.9 & 7.8 & S. sivalensis \\
\hline D-197 & 14,1 & 9,1 & S. indicus \\
\hline YPM 13828/D-189/190c & 14.1 & 11.6 & S. indicus \\
\hline GSI-18039 & 12.7 & 10.0 & S. indicus \\
\hline Bandal, India & & & \\
\hline ONGC V/790 & $16^{*}$ & $9.2 *$ & S. lewisi Holotype \\
\hline $\begin{array}{l}\text { Potwar Plateau localities, } \\
\text { Pakistan }\end{array}$ & & & \\
\hline AMNH 19412b & 11.3 & 7.5 & S. sivalensis \\
\hline GSP 9563e & 11.5 & 6.3 & S. sivalensis \\
\hline GSP 13445e & 10.4 & 6.5 & S. sivalensis \\
\hline GSP 6160e & 11.1 & 6.5 & S. sivalensis \\
\hline GSP 15000f & 13.4 & 8.7 & S. indicus \\
\hline GSI D-298g & 9.8 & 5.5 & S. simonsi Holotype \\
\hline BSPhG 1939 X4h & 17.4 & 9.9 & S. parvada Holotype \\
\hline
\end{tabular}


$\mathrm{m} / 2$. This specimen, originally interpreted as a lower incisor, is in fact a lower $\mathrm{m} / 1$, marked distally by a deep interstitial facet made by abrasion against the $\mathrm{m} / 2$. The groove between the hypoconid and hypoconulid is preserved and the hypoconulid itself is antero-posteriorly compressed.

SFP 192 is the buccal cusp of a left P3/ (Fig. 4a), showing anterior and posterior contact facets produced by the neighbouring teeth. The mesial and distal "shoulders" of the tooth are relatively high and the buccal enamel surface between them curves strongly rootwards. For the Siwaliks this is an exceptionally small hominoid tooth (Table 5).

Table 5. Measurements (in mm) of the Dera Gopipur P3/, VPL/ RP-H1 from Dangar, India, and means of Sivapithecus species. Sivapithecus metrics are means from Kay (1982) and Kelley (1988), RP-H1 is from Patnaik \& Cameron (1997).

\begin{tabular}{|l|c|}
\hline Species & Maximum length \\
\hline Sivapithecus parvada & 8.1 \\
\hline Sivapithecus indicus & 9.2 \\
\hline Sivapithecus sivalensis & 9.0 \\
\hline Sivapithecus hysudricus (ex-simonsi) & 7.9 \\
\hline RP-H1 (Dangar) & 7.0 \\
\hline Dera Gopipur & 6.2 \\
\hline
\end{tabular}

SFP 193 is a fragment of enamel with coarsely wrinkled surface, sporting a small basal cusplet called the metaconid by Gupta et al. (1982), who considered the specimen to be a lower canine. Because of the presence of a small basal cusplet the specimen is likely not a canine; it is so fragmentary that it is doubtfully primate, possibly from a suid or a tragulid.

\section{INTERPRETATION}

In the overall context of Siwalik hominoids, the Dera Gopipur teeth are extremely small, falling within the lower part of, or below the range of metric variation of Sivapithecus sivalensis. In some measurements the teeth are slightly smaller than those of Sivapithecus hysudricus, but in others they are somewhat greater. Judging from the morphology of the $\mathrm{p} / 3$, the Dera Gopipur material is female, and this explains, to some extent, its small dimensions. Further material is required to throw light on this possibility.

In any case $S$. hysudricus is extremely rare, only a few specimens having been attributed to it: GSI-D 200 (holotype $\mathrm{m} / 1$ from Hari Talyangar); YPM 13814, from Hasnot, Pakistan [type specimen of Bramapithecus thorpei Lewis, 1934, considered by Simons (1964), and Simons \& Pilbeam (1965), to represent Ramapithecus punjabicus]; M 15423, left mandible containing roots of $\mathrm{p} / 3$ and crowns of $\mathrm{p} / 4-\mathrm{m} / 2$, from Domeli, Pakistan [= M 15243 in Simons \& Pilbeam (1965), Dryopithecus laietanus Villalta
\& Crusafont, 1944]; BSPG 1939 X 1, right M1/, Kundal Nala; BSPG 1956 II 2366 [Field N 750 (9-12-55)], left $\mathrm{p} / 3$ from Kadirpur, Pakistan; GSI D-298, right mandible with $\mathrm{p} / 3-\mathrm{m} / 2$ from Kundal Nala, near Chinji, Pakistan [= GSI D 618 in Simons \& Pilbeam (1965), Dryopithecus laietanus; = type specimen of Sivapithecus simonsi, Kay, 1982]; GSI D 185, right maxilla containing P3/-M2/, from Hari Talyangar, India; SFP 187 - left M2/, SFP 188 - right M2/, SFP 189 - right m/2, SFP 190 - left p/3, SFP 191 - right m/1 fragment, SFP 192 - left P3/ fragment, from Dera Gopipur, India (Gupta et al., 1982).

\section{DHARA AND NUNGARH}

\section{CONTEXT}

Sahni et al. (1974, 1980, 1983), Sahni \& Tiwari (1979) and Tiwari \& Kumar (1984) provided written and map indications of the discovery locus of a hominoid upper molar from Dhara that they attributed to Ramapithecus punjabicus. The location of the find was described as being $2 \mathrm{kms}$ north of Dhara village in the Dhara Reserve Forest, Uttar Pradesh. The map published by Cameron et al. (1999) is at a large scale but does not provide a precise position of the site [note that Kalagarh (as given in title) and Kashmir are inaccurately mentioned as Districts whereas the former is a town in Pauri Garhwal District and the later is a regional entity of Jammu \& Kashmir State of India]. The text repeats the location given by the Tiwari \& Kumar (1984) as $2 \mathrm{kms}$ north of Dhara village.

The map in Tiwari \& Kumar (1984) shows the discovery locus near a prominent bend in the course of the Dhara River. We have determined the position of the locality $\left(29^{\circ} 28^{\prime} 04.2^{\prime \prime} \mathrm{N}: 78^{\circ} 50^{\prime} 55.4^{\prime} \mathrm{E}\right)$ using Google Earth (Fig. 6), but it should be borne in mind that the fossil was found in a loose boulder in the bed of the river. The locality of Nungarh $\left(29^{\circ} 29^{\prime} 32.5^{\prime \prime} \mathrm{N}: 7^{\circ} 49^{\prime} 08.2^{\prime \prime} \mathrm{E}\right.$; see Tiwari, 1982) which yielded a tooth interpreted as a lower premolar of a hominoid, is ca $4 \mathrm{~km}$ northwest of the Dhara hominoid site (Fig. 6).

\section{PALAEOANTHROPOLOGY}

LUVP 7045, the upper molar from Dhara is small for a Siwalik hominoid, and probably belongs to Sivapithecus sivalensis (see Cameron et al., 1999) or possibly Sivapithecus hysudricus.

LUVP 7005 from Nungarh, was interpreted as a left $\mathrm{p} / 3$ by Cameron et al. (1999) who concluded that "While it is metrically closer to the scores observed in S. sivalensis from Hari Talyangar, its specific status remains problematic". The specimen has a single root, broken lingually (Fig. 7, 8), the enamel extends further rootwards disto-buccally than it does mesio-buccally (Fig. 8e), it has a prominent central ridge descending from its apex down the lingual side of the crown (originally complete but now 


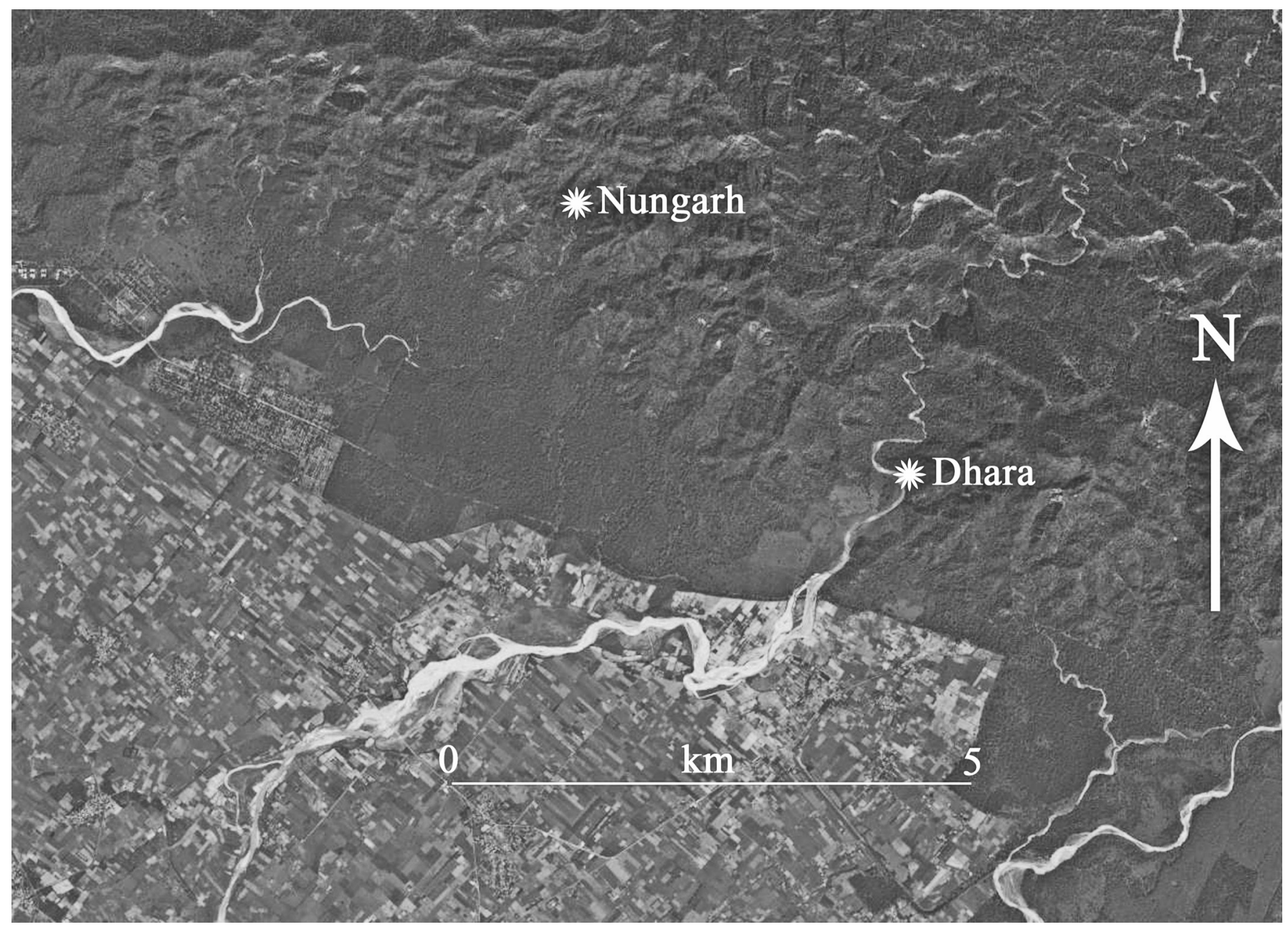

Figure 6. Location of the Dhara hominoid molar and Nungarh tooth, Uttar Pradesh, India (image modified from Google Earth).

with a broken part in the middle), and on this ridge there is a groove basally. The wear facet which slopes lingually apically, bends both mesially and distally towards cervix, the mesial part appreciably more capacious than the distal one (Fig. 8d), thereby removing enamel from most of the surface of the tooth (Fig. 7d). There is an "indent" [a
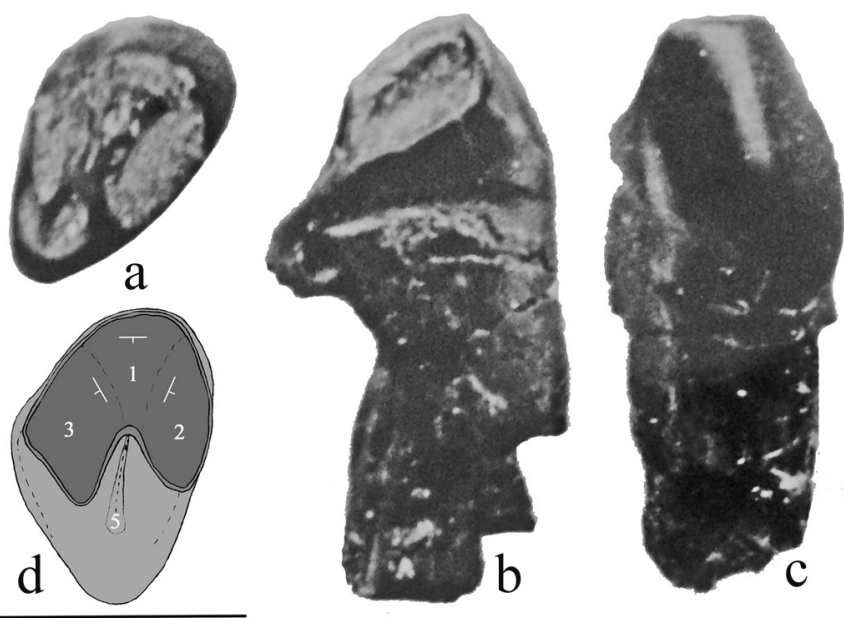

horizontal groove worn beneath cervix mesially which extends right across the specimen from buccal to lingual sides (4 in Fig. 8)]. There is no sign of a honing facet and the enamel is too thin for the tooth to belong to a hominoid. In addition, the microwear (Fig. 9) is inconsistent with primates, but resembles that induced in carnivore incisors when they repeatedly tug at hair-covered skin during the processing of prey items.

In view of the crown morphology, positions and inclinations of major wear facets, and the pattern of micro-

Figure 7. LUVP 7005, carnivore upper incisor from Nungarh, India, previously interpreted as a left $\mathrm{p} / 3$ of a hominoid, illustrated prior to damage occurring to the crown and root (images a-c are from Plate 6 of Tiwari, 1982). a, occlusal; b, mesial; c, labial; d, apical views. In image $\mathbf{d}$, note the three contiguous wear facets (1, apical; 2, mesial; 3, distal) dipping lingually, mesially and distally respectively, and the presence of a narrow groove on the lingual ridge (5) and the thin enamel (Scale $10 \mathrm{~mm}$ ). 


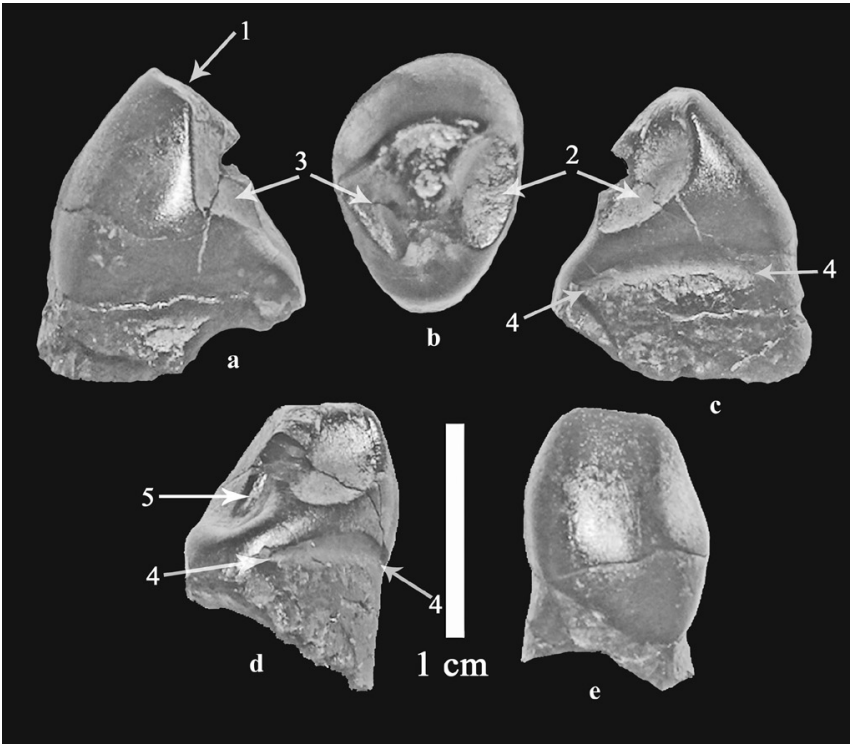

Figure 8. SEM images of LUVP 7005, tooth from Nungarh, Uttar Pradesh, India (same specimen as in Figure 7). a, distal; b, apical; c, mesial; d, antero-lingual; e, labial views. Note the damaged lingual ridge which significantly complicates interpretation of the fossil. The apical wear facet (1) is contiguous with two scoopshaped depressions (2, mesial; $\mathbf{3}$, distal) which are not foveae as previously thought, but were produced by wear. Note the narrow groove (5) near the base of the lingual ridge, and the "indent" (4) extending right across the root immediately beneath cervix on the mesial side of the tooth. Note also the thin enamel (Images courtesy of Rajeev Patnaik).

wear, we consider that this specimen does not belong to a primate, but that it is likely to represent an upper lateral incisor of a large carnivore, possibly an amphicyonid. The combination of an apical wear facet dipping lingually, accompanied by two wear facets descending mesially and distally, and the presence of an "indent" often occurs in carnivores that tug at skin and sinews of their prey, the fibrous tissues producing a groove-like wear channel on the root at gingival level, and the tugging producing pervasive wear of the crown (Fig. 9), especially where the upper and lower incisors interlock.

\section{RAMCHAND RIDGE: PALAEONTOLOGY}

The anterior half of a lower molar from the "southeast face of Ramchand Ridge, south of Ramnagar" in the Dodenal Member of the Mansar Formation (GSI 20825 (JVF 297) curated in Lucknow) was attributed to Sivapithecus sp. by Verma \& Gupta (1997) and Verma et al. (2002). It is in fact the anterior lophid of a left lower $\mathrm{m} / 3$ of the suid Conohyus. The specimen is $14.6 \mathrm{~mm}$ in bucco-lingual breadth. The protoconid and metaconid are robust, thickly enamelled cusps with subdued "furchen" with coarsely wrinkled enamel. The tooth is moderately worn, and the
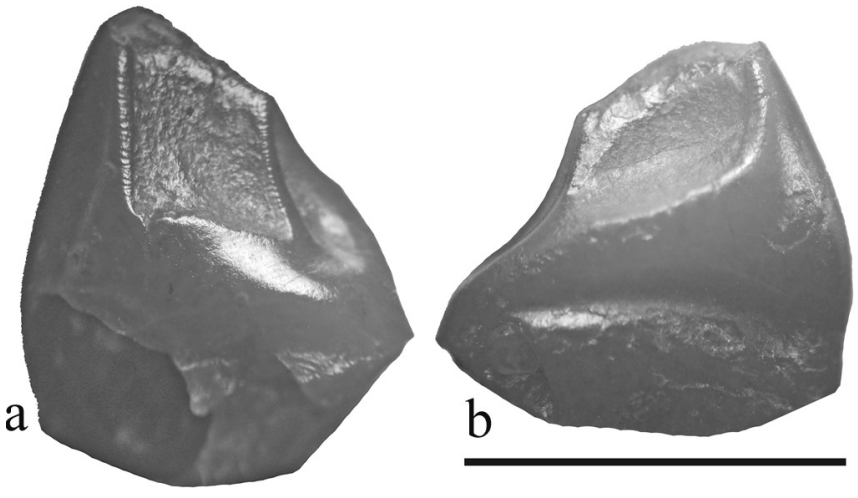

Figure 9. LUVP 7005 from Nungarh, Uttar Pradesh, India, carnivore upper incisor, a, distal view of crown showing large distal wear facet bordered by thin enamel scored by numerous narrow grooves sub-parallel to cervix, probably caused by hair abrasion during tugging at skin of prey items. Note also the highly polished enamel surface scored by long striations; b, mesial view of crown showing similar but fewer narrow grooves in the enamel, and a large "indent" beneath cervix. The position of the major wear facets, the thin enamel, the presence of an "indent" beneath cervix mesially and the microwear indicate that this tooth does not belong to a primate, but more likely to a carnivore.

roots are fused for a short distance beneath cervix. This tooth evidently represents the species Conohyus sindiensis (Lydekker, 1884) as it is compatible in size with teeth of this species (Pickford, 1988).

\section{DHIRAN: PALAEONTOLOGY}

Specimen GSI 20826 (JVF 518) from the basal part of the Ramnagar Member of the Mansar Formation "near Dhiran Village, south of Ramnagar" was identified as an isolated upper incisor of Dryopithecus sp. by Verma \& Gupta (1997) and Verma et al. (2002). The specimen, which is stored in Lucknow, is a left $\mathrm{i} / 1$ of the lophodont suid Listriodon pentapotamiae (Falconer, 1868). Similar specimens are known in mandibles from the Siwaliks and Europe (Pickford, 1988).

\section{BANDAL}

\section{PALAEONTOLOGY}

Gupta (1969) described two fossil specimens from three miles (ca $5 \mathrm{~km}$ ) east of Bandal, Himachal Pradesh $\left(32^{\circ} 01^{\prime} 38^{\prime \prime} \mathrm{N}: 76^{\circ} 14^{\prime} 11^{\prime \prime} \mathrm{E}\right)$ from rocks correlated to the Nurpur zone which were reported to be equivalent to the Chinji Zone of the Lower Siwaliks. The fossils were attributed to Sivapithecus indicus, and were claimed to represent "the oldest record of the occurrence of fossil primates from the lower Siwaliks of India". Examination of 
the illustrations (Gupta, 1969: Figs 1, 2) reveal that both fossils belong to Suidae. The supposed left mandible interpreted to contain the fourth premolar and second molar is in fact a right maxilla with P4/-M1/ of Propotamochoerus hysudricus (Pickford, 1988) as shown by the presence of three cusps (two buccal, one lingual) in the P4/ and four cusps in the M1/, the bunodont aspect of the teeth and the size relationship between the $\mathrm{P} 4 /$ and the $\mathrm{M} 1 /$. The second specimen from the site is also an upper right $\mathrm{P} 4 /$, more worn than the first specimen but with similar morphology.

The bunodont morphology and dimensions of the Bandal suid teeth are compatible with two species known from the Siwaliks, Hyotherium pilgrimi and Propotamochoerus hysudricus. The available illustrations are rather dark, making them difficult to interpret, but the specimens resemble Propotamochoerus hysudricus rather more than they do Hyotherium pilgrimi. Only a re-examination of the original fossils will permit a confident identification.

The Bandal specimens cannot therefore be used to infer a great age for the occurrence of Sivapithecus indicus in India.

Nevertheless, there is a mandible of Sivapithecus from a different locality at Bandal, described by Pandey \& Sastri (1968).

\section{PALAEOANTHROPOLOGY}

Sivapithecus lewisi was described by Pandey \& Sastri (1968), on the basis of a partial right mandible of large dimensions (Fig. 10) found at Bandal, India $\left(32^{\circ} 01^{\prime} 55^{\prime} \mathrm{N}\right.$ : 76 $\left.16^{\prime} 15^{\prime \prime} \mathrm{E}\right)$ not far from Dera Gopipur. The holotype, $\mathrm{ONGC} / \mathrm{V} / 790$, is a right mandible with roots of the canine
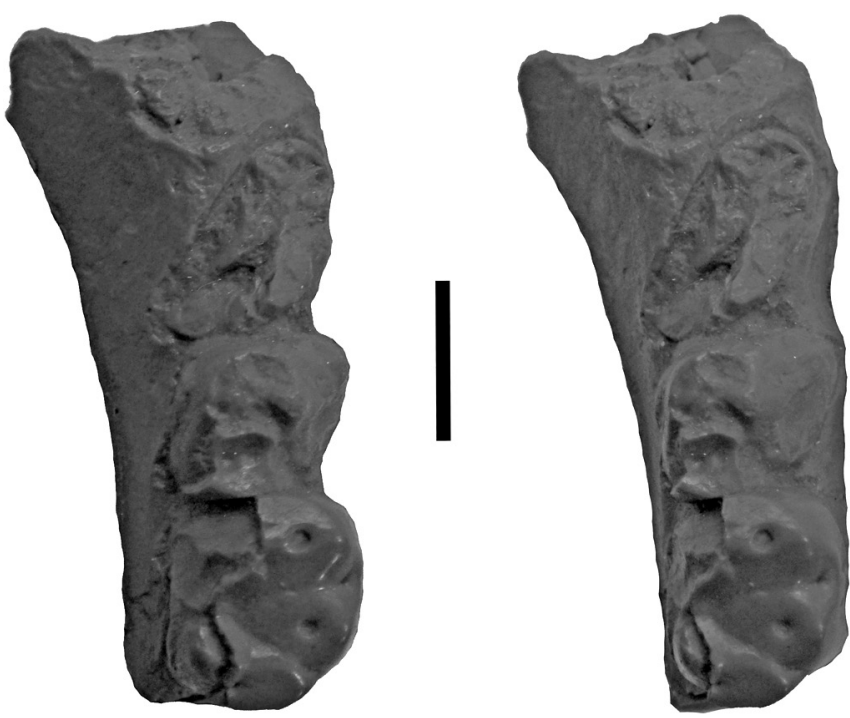

Figure 10. Sivapithecus lewisi Pandey \& Sastri, 1968, ONGC/V/790, holotype, right mandible fragment containing the roots of canine and $\mathrm{p} / 3$ and the crowns of $\mathrm{p} / 4$ (lacking most of the enamel) and $\mathrm{m} / 1$, from Bandal, India, stereo occlusal view (scale: $10 \mathrm{~mm}$ ). and $\mathrm{p} / 3$, crowns of $\mathrm{p} / 4$ and $\mathrm{m} / 1$, and is curated at the Oil and Natural Gas Commission, Dehra Dun. Subsequently, Kelley (1988), created the species Sivapithecus parvada for large hominoid specimens from Sethi Nagri, Pakistan. Examination of the Bandal specimen reveals that it belongs to the same species as that from Sethi Nagri, and thus $S$. parvada Kelley, 1988, is a junior synonym of S. lewisi Pandey \& Sastri, 1968.

The holotype of Sivapithecus aiyengari Prasad, 1962, which is a left mandible from Hari Talyangar containing worn $\mathrm{p} / 3-\mathrm{m} / 2$, falls into the range of morphological and metric variation of Sivapithecus indicus as was shown by Kelley (1988). Our own analysis of the jaw using the dimensions of the teeth given by Prasad (1968) and a visual inspection of the specimen (GSI 18039) housed in the Geological Survey of India, Calcutta, agrees with this finding (Fig. 11).

Table 6. Measurements (in $\mathrm{mm}$ ) of the teeth of the holotype of Sivapithecus lewisi (ONGC V/790) from Bandal, India (* estimated measurement).

\begin{tabular}{|l|c|c|}
\hline Tooth & Mesio-distal length & Bucco-lingual breadth \\
\hline Right $\mathrm{p} / 3$ & $16^{*}$ & $9.2^{*}$ \\
\hline Right $\mathrm{p} / 4$ & $11.0^{*}$ & $11.6^{*}$ \\
\hline Right $\mathrm{m} / 1$ & $13.7^{*}$ & 12.0 \\
\hline
\end{tabular}

\section{BHARARI}

\section{CONTEXT}

Sankhyan (1985) reported that a hominoid tooth was found in strata west of Bharari and $2 \mathrm{~km}$ east of Hari Talyangar, aged about $5.5 \mathrm{Ma}$, which would mean that it is, by far, the youngest hominoid fossil from India (not counting Pleistocene hominoids). However, the palaeomagnetic data for the Hari Talyangar succession, which was used to determine the age of the specimen, was reinterpreted by Pillans et al. (2005) using the GPTS (Geomagnetic Polarity Time Scale) of Brozovic \& Burbank (2000), and the R7 polarity chron from which the Bharari molar is reported to have been collected (Sankhyan, 1985) would, in this reinterpretation, be about 8.1 Ma. However, Sankhyan (1985) appears to have misnumbered the chrons above R6. Whereas Johnson et al. (1983) show three normal polarity zones above R6 (N7, N8 and N9), Sankhyan (1985) numbered the two lower zones as N7 and the top one as N8. Thus the reported find level of the Bharari tooth should probably be R8 rather than R7. Even with this adjustment, the age of the tooth would likely be about $8 \mathrm{Ma}$ to $7.5 \mathrm{Ma}$. However, considering the possibility of circular argument when employing palaeomagnetic stratigraphy (Pickford, 1998), it is best not to rely too much on this evidence for dating the tooth. However, an age of 5.5 Ma appears to be far too young for it. 

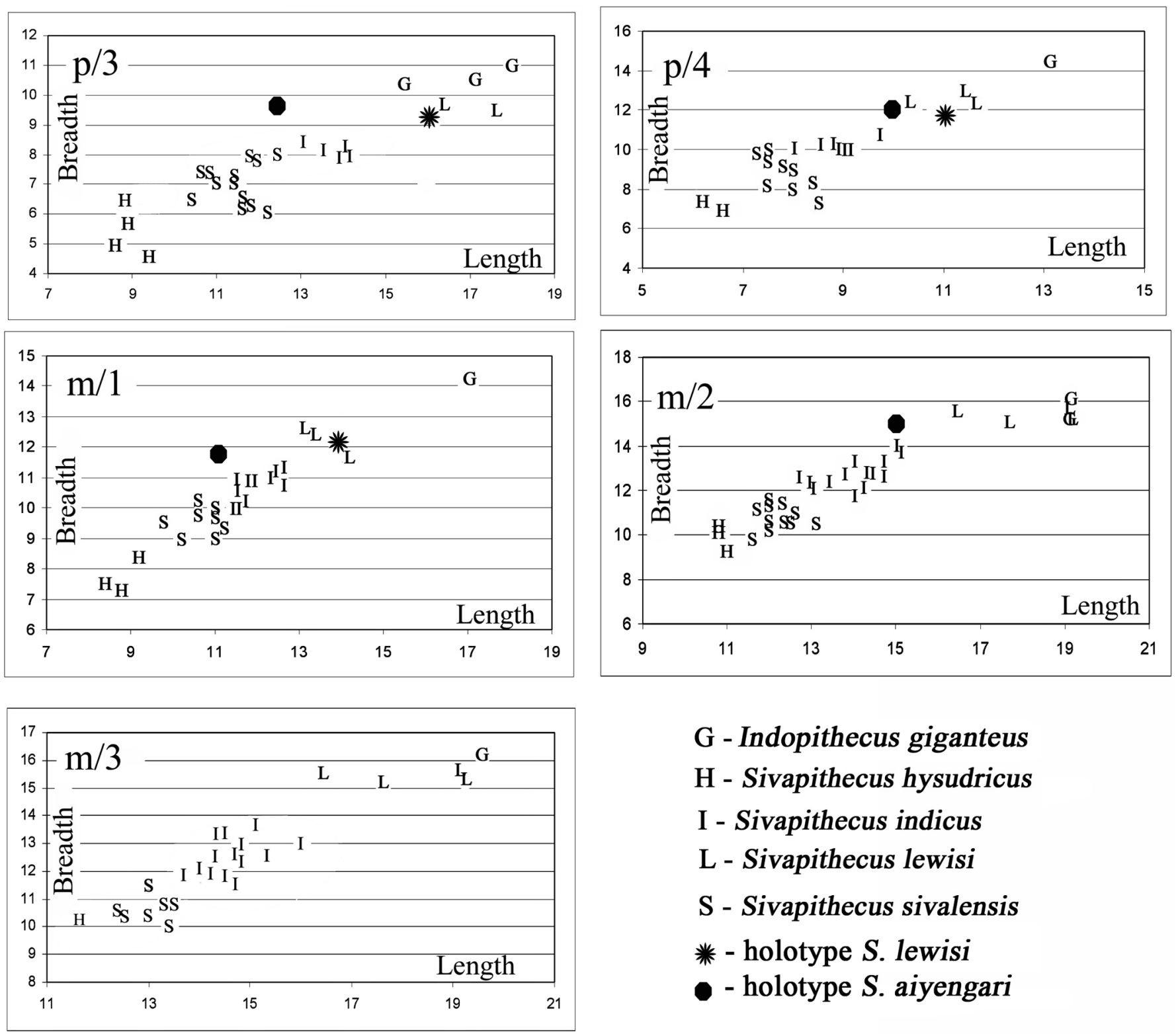

\section{G - Indopithecus giganteus \\ H - Sivapithecus hysudricus \\ I - Sivapithecus indicus \\ L - Sivapithecus lewisi \\ S - Sivapithecus sivalensis \\ - holotype $S$. lewisi \\ - holotype $S$. aiyengari}

Figure 11. Bivariate plots of lower cheek teeth of Siwalik hominoids (Sivapithecus and Indopithecus species). Included are the teeth from Dera Gopipur, here attributed to Sivapithecus hysudricus (Pilgrim, 1927), and the specimen from Bandal belonging to Sivapithecus lewisi Pandey \& Sastri, 1968.

\section{PALAEOANTHROPOLOGY}

Sankhyan (1985) interpreted a fragmentary tooth from Middle Siwalik deposits 500 metres west of Bharari $\left(31^{\circ} 32^{\prime} 20^{\prime} \mathrm{N}: 76^{\circ} 39^{\prime} 40^{\prime \prime} \mathrm{E}\right) \mathrm{ca} 2 \mathrm{~km}$ east of Hari Talyangar, as representing a lower right second molar of Sivapithecus. The linguo-mesial part of the metaconid is broken (Fig. 12). The distal interstitial wear facet was described by Sankhyan as being distinct and rounded and positioned on the posterior aspect of the tooth and the mesial interstitial facet is partly preserved despite the broken metaconid. This combination is compatible with interpretation of the tooth as an $\mathrm{m} / 1$ or an $\mathrm{m} / 2$. In view of its fragmentary nature, the orientation of the intercuspal valleys and the position of the interstitial facets, this tooth needs to be re-examined in order to confirm its meristic position and affinities.

\section{DISCUSSION AND CONCLUSIONS}

There remains some uncertainty about the discovery locus of fossil hominoid teeth from Dera Gopipur (Gupta et al., 1982) on account of the presence of contradictions between the map, the photograph and the text of the paper describing the specimens.

Examination of the fossils reveals that some of the previous determinations of side and meristic positions are 

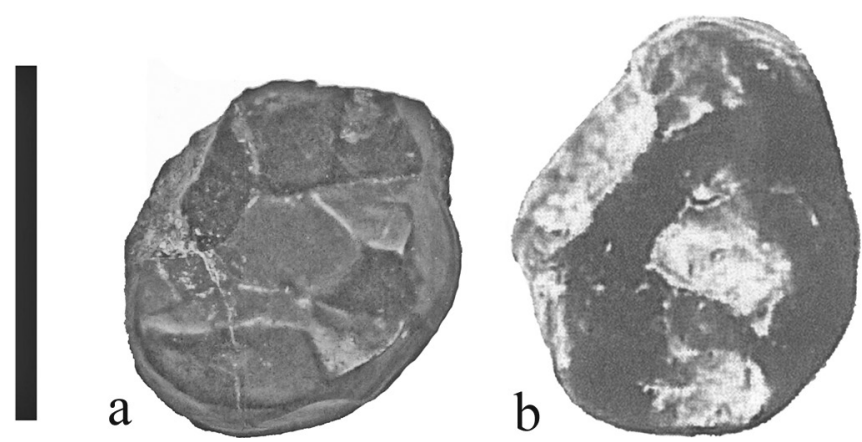

Figure 12. Comparison of the Dera Gopipur right $\mathrm{m} / 2$ (a) with a specimen from Bharari (b) (image of Bharari specimen from Sankhyan, 1985) (scales: $10 \mathrm{~mm}$ ).

incorrect. In comparison with other fossil hominoid teeth from the Siwaliks of the Indian Subcontinent, the Dera Gopipur fossils are small, falling near the low end of the range of variation of Sivapithecus sivalensis or beyond it. The shape of the $p / 3$ in the Dera Gopipur sample suggests that it represents a female individual. We here attribute the material to Sivapithecus hysudricus.

There are almost no other fossils associated with these hominoid teeth, making it impossible to estimate their age on the basis of biochronology. Correlations of the strata, from which the teeth are reported to have been excavated, remain uncertain, although they have been considered to be equivalent to the Chinji zone by Verma et al. (2002).

Kelley (1988) wrote that small Siwalik hominoids are generally geologically younger than the large ones. According to him, S. sivalensis is best known from Hari Talyangar, correlated by him to the Dhok Pathan zone which is appreciably younger than Sethi Nagri which yielded Sivapithecus parvada and other sites in the Potwar Plateau, Pakistan, up to the U-sandstone level which contain Sivapithecus indicus. Thus, if Kelley (1988) is right, then a correlation of Dera Gopipur to the Chinji zone may be too old. However, most of the specimens attributed to Sivapithecus hysudricus come from the Chinji type area (Kundal Nala, Kadirpur), and we see no great obstacle to correlating Dera Gopipur to the Chinji zone.

The Dhara (Uttarakhand) hominoid molar also probably belongs to $S$. sivalensis or possibly to $S$. hysudricus. The report of a $\mathrm{p} / 3$ from Dhara (Cameron et al., 1999) is based on a single rooted tooth from Nungarh (Uttarakhand) (Tiwari, 1982) which we consider to represent a carnivore incisor.

Two supposed hominoid teeth from Ramchand Ridge and Dhiran near Ramnagar (J\&K), are here identified as suids. The inferred presence of Early Miocene (18.3 Ma) large hominoids in India (Verma \& Gupta, 1997) cannot be substantiated on the basis of these fossils. Finally, two specimens reported to be from the Nurpur Zone near Bandal (HP), attributed to Sivapithecus indicus by Gupta (1969) belong to suids, and cannot therefore be used to infer a great age for the presence of hominoids in India.
Nevertheless, the Bandal region has yielded a large Sivapithecus mandible, here attributed to $S$. lewisi Pandey \& Sastri, 1968, of which Sivapithecus parvada Kelley, 1988, is a junior synonym.

The earliest well substantiated records of large hominoids in India are those from Ramnagar from deposits which are probably equivalent in age to Chinji levels, and thus about 13-11.5 million years old. The fossil molar from Dhara is likely to be somewhat younger, perhaps ca 11-10 Ma (Cameron et al., 1999). The Indian evidence thus accords with that of Pakistan, with large bodied hominoids currently unknown from levels older than $13 \mathrm{Ma}$. This contrasts with Europe, where large hominoids have been reported in MN 5 (or MN 5-6) (Engelswies, Germany: Heizmann, 1992; Heizmann \& Begun, 2001) and MN 6 (Candir and Pasalar, Turkey; ca 14 Ma: Andrews et al., 1996). The dating of the European deposits is the subject of debate (Agustí et al., 2001) but Heizmann \& Begun (2001) estimated an age of 16.5 Ma for Engelswies. Pickford (1998) in contrast dated Engelswies at ca $14 \mathrm{Ma}$. The Hari Talyangar hominoids (ca 8-7 Ma) are among the youngest known from the subcontinent, although a doubtful claim for an even younger specimen (ca 5.5 Ma) has been made (Sankhyan, 1985). If our assessment of the ages of the Indian fossils is correct, then it is concluded that large bodied hominoids survived in the subcontinent from ca 13 to ca 8-7 Ma (Pickford, 1998).

\section{ACKNOWLEDGEMENTS}

We thank the Director of the Wadia Institute of Himalayan Geology for encouragement to carry out field work in Himachal Pradesh. We also thank A. Bhandari and R. Sehgal for discussions and help. Thanks to Rajeev Patnaik for the SEM images and casts of the Nungarh LUVP 7005 and Dominique Gommery for assistance with literature.

\section{REFERENCES}

Agustí, J., Cabrera, L., Garcés, M., Krijgsman, W., Oms, O. \& Parés, J.M. 2001. A calibrated mammal scale for the Neogene of Western Europe. State of the Art. EarthScience Reviews, 52, 247-260.

Andrews, P., Harrison, T., Delson, E., Bernor, R. \& Martin, L. 1999. Distribution and biochronology of European and Southwest Asian Miocene Catarrhines. In: The Evolution of Western Eurasian Neogene Mammal Faunas (eds. R. Bernor, V. Fahlbusch \& H.-W. Mittmann). Columbia University Press, New York, 168-207.

Brozovic, N. \& Burbank, D.W. 2000. Dynamic fluvial systems and gravel progradation in the Himalayan foreland. $B u$ lletin of the Geological Society of America, 112, 394-412.

Cameron, D., Patnaik, R. \& Sahni, A. 1999. Sivapithecus dental specimens from Dhara locality, Kalgarh District, 
Uttar Pradesh, Siwaliks, Northern India. Journal of Human Evolution, 37, 861-868.

Chopra, S.R.K. \& Kaul, S. 1975. New fossil Dryopithecus material from the Nagri Beds at Haritalyangar (H.P.), India. In: Contemporary Primatology (eds. S. Kondo, M. Kawai \& A. Ehara). S. Karger, Basel, 2-11.

Falconer, H. 1868. Palaeontological memoirs and notes of the late Hugh Falconer, vol. 1, Fauna antiqua sivalensis. C. Murchinson, London, $145 \mathrm{pp}$.

Gregory, W. K. \& Hellman, M. 1926. The dentition of Dryopithecus and the origin of man. Anthropology Papers of the American Museum of Natural History, 28, 1-123.

Gupta, S.S., Verma, B.C. \& Tewari, A.P. 1979. New fossil hominoid material from the Middle Siwaliks of Kangra District, Himachal Pradesh. IGCP-41. Neogene/Quaternary Boundary: Field Conference, India, 1979, 11.

Gupta, S.S., Verma, B.C. \& Tewari, A.P. 1982. New fossil hominoid material from the Siwaliks of Kangra District, Himachal Pradesh. Journal of the Palaeontological Society of India, 27, 111-115.

Gupta, V.J. 1969. Fossil primates from the Lower Siwaliks of Kangra District, H.P. Research Bulletin (N.S.) of the Panjab University, 20, 577-578.

Heizmann, E., 1992. Das Tertiär in Südwestdeutschland. Stuttgarter Beiträge zur Naturkunde, Serie C, 33, 1-90.

Heizmann, E. \& Begun, D. 2001. The oldest Eurasian hominoid. Journal of Human Evolution, 41, 463-481.

Johnson, G.D., Opdyke, N.D., Tandon, S.K. \& Nanda, A.C. 1983. The magnetic polarity stratigraphy of the Siwalik Group at Haritalyangar (India) and a new last appearance datum for Ramapithecus and Sivapithecus in Asia. Palaeogeography, Palaeoclimatology, Palaeoecology, 44, 223-249.

Kay, R. 1982. Sivapithecus simonsi, a new species of Miocene hominoid with comments on the phylogenetic status of the Ramapithecinae. International Journal of Primatology, 3, 113-174.

Kelley, J. 1988. A new large species of Sivapithecus from the Siwaliks of Pakistan. Journal of Human Evolution, 17, 305-324.

Kelley, J. 2005. Misconceptions arising from the misassignment of non-hominoid teeth to the Miocene hominoid Sivapithecus. Palaeontologia Electronica, 8, 16A, 1-19.

Lewis, G. 1934. Preliminary notice of new man-like apes from India. American Journal of Science, 27, 167-179.

Lydekker, R. 1879. Further notices of Siwalik mammalian. Records of the Geological Survey of India, 11, 33-57.

Lydekker, R. 1884. Indian Tertiary and post-Tertiary Vertebrata. Siwalik and Narbada Bunodont Suina. Memoirs of the Geological Survey of India, Palaeontologica indica, 10 (3) 2, 35-104.

Munthe, J., Dongol, B., Hutchison, J., Kean, W., Munthe, K. $\&$ West, R. 1983. New fossil discoveries from the Miocene of Nepal including a hominoid. Nature, 303, 331-333.

Pandey, J. \& Sastri, V.V. 1968. On a new species of Sivapithecus from the Siwalik rocks of India. Journal of the Geological Society of India, 9, 206-211.

Patnaik, R. \& Cameron, D. 1997. New Miocene fossil ape lo- cality, Dangar, Hari-Talyangar region, Siwaliks, Northern India. Journal of Human Evolution, 32, 93-97.

Patnaik, R., Cameron, D., Sharma, J.C. \& Hogarth, J. 2005. Extinction of Siwalik fossil apes: a review based on a new fossil tooth and on palaeoecological and palaeoclimatological evidence. Anthropological Science, 113, 65-72.

Pickford, M. 1977. The status of Adaetontherium incognitum Lewis, 1934 from the middle Miocene of Pakistan. Tertiary Research, 1, 67-68.

Pickford, M. 1988. Revision of the Miocene Suidae of the Indian Subcontinent. Münchner Geowissenschaftliche Abhandelungen, 12, 1-91.

Pickford, M. 1998. Dating of the Neogene Old World anthropoid fossil record: essential base for phylogenetic analysis, biogeography and palaeoecology. Primatologie, 1, 27-92.

Pilbeam, D.R., Rose, M.D., Badgley, C. \& Lipschutz, B. 1980. Miocene Hominoids from Pakistan. Postilla, 181, 1-94.

Pilgrim G. 1910. Notices of new mammalian genera and species from the Tertiaries of India. Records of the Geological Survey of India, 40, 63-71.

Pilgrim, G.E. 1927. A Sivapithecus palate and other primate fossils from India. Palaeontologica indica, 14, 1-26.

Pillans, B., Williams, M., Cameron, D., Patnaik, R., Hogarth, J., Sahni, A., Sharma, J., Williams, F. \& Bernor, R. 2005. Revised correlation of the Haritalyangar magnetostratigraphy, Indian Siwaliks: implications for the age of the Miocene hominoids Indopithecus and Sivapithecus, with a note on a new hominid tooth. Journal of Human Evolution, 48, 507-515.

Prasad, K.N. 1962. Fossil primates from the Siwalik Beds near Haritalyangar, Himachal Pradesh, India. Journal of the Geological Society of India, 3, 86-96.

Prasad, K.N. 1968. The vertebrate fauna from the Siwalik Beds of Haritalyangar, Himachal Pradesh, India. Palaeontologica indica, 39, 1-77.

Pruess, T.M. 1982. The face of Sivapithecus indicus: Description of a new, relatively complete specimen from the Siwaliks of Pakistan. Folia Primatologica, 38, 141-157.

Sahni, A. \& Tiwari, B.N. 1979. Lower Siwalik vertebrates from Kalagarh District Pauri Garwhal, U.P. Himalayan Geology, 9, 339-347.

Sahni, A., Kumar, V. \& Srivastava, V.C. 1974. Dryopithecus (subgenus Sivapithecus) and associated vertebrates from the Lower Siwaliks of Uttar Pradesh. Bulletin of the Indian Geological Association, 7, 54.

Sahni, A., Tiwari, B.N. \& Kumar, K. 1980. An additional Lower Siwalik vertebrate fauna from the Kalagarh Area, District Pauri Garhwal, Uttar Pradesh. Proceedings of the $3^{\text {rd }}$ Indian Geological Congress, Poona, 81-90.

Sahni, A., Tiwari, B.N. \& Kumar, K. 1983. A report on the occurrence of Ramapithecus punjabicus (Hominoidea) from the Uttar Pradesh Siwaliks. Himalayan Geology, 11, 193-197.

Sankhyan, A.R. 1985. Late occurrence of Sivapithecus in Indian Siwaliks. Journal of Human Evolution, 14, 573-578.

Simons, E.L. 1964. On the mandible of Ramapithecus. Proceedings of the National Academy of Sciences (USA), 51, 528-535. 
Simons, E.L. \& Pilbeam, D.R. 1965. Preliminary revision of the Dryopithecinae (Pongidae, Anthropoidea). Folia Primatologia, 3, 81-152.

Tiwari, B.N. 1982. Geology and Vertebrate Palaeontology of the Siwalik Group of Kalagarh-Koti Rao Section, District Pauri Garhwal (UP) with Special Reference to Palaeohistological Studies. Ph. D. Thesis, Geology Department, University of Lucknow, 304 pp. (Unpublished).

Tiwari, B.N. \& Kumar, K. 1984. A new locality for Ramapithecus (Hominoidea): Lower Siwaliks of the Dhara Reserve Forest, Uttar Pradesh. Man and Environment, 8, 8-12.

Verma, B.C., Mishra, V.P. \& Gupta, S.S. 2002. Pictorial Catalogue of Siwalik Vertebrate Fossils from Northwest
Himalaya. Geological Survey of India Catalogue Series, 5, 1-378.

Verma, B.C. \& Gupta, S.S. 1997. New light on the antiquity of Siwalik Great Apes. Current Science, 72, 302-303.

Villalta, J.F. de \& Crusafont, M. 1944. Dos nuevos Antropomorfos del Mioceno español y su situación dentro de la moderna sistemática de los Símidos. Notas y Coтиnicaciones del Instituto Geológico y Minero de España, 13, 91-139.

Manuscrito recibido: 2 de Junio, 2010 Manuscrito aceptado: 30 de Octubre, 2010 